\title{
Closing the development finance gap in post- conflict and fragile situations: What role for development finance institutions?
}

\section{Thierry Giordano \& Michele Ruiters}

To cite this article: Thierry Giordano \& Michele Ruiters (2016) Closing the development finance gap in post-conflict and fragile situations: What role for development finance institutions?, Development Southern Africa, 33:4, 562-578, DOI: 10.1080/0376835X.2016.1179102

To link to this article: http://dx.doi.org/10.1080/0376835X.2016.1179102

\section{Published online: 23 May 2016.}

Submit your article to this journal $\pi$

Џll Article views: 117

Q View related articles $\square$

View Crossmark data ¿ 


\title{
Closing the development finance gap in post-conflict and fragile situations: What role for development finance institutions?
}

\author{
Thierry Giordano ${ }^{a}$ and Michele Ruiters ${ }^{b}$ \\ ${ }^{a}$ Researcher, Economy and Society Department, CIRAD, UMR ART-DEV - Acteurs, Ressources et Territoires \\ dans le Développement, Montpellier, France; ${ }^{\mathrm{b}}$ Regional Integration Specialist, Strategy Division, Development \\ Bank of Southern Africa, Midrand, South Africa
}

\begin{abstract}
For many years, the main focus of international institutions and bilateral aid agencies has been on state building as the main action to support countries' recovery from conflicts or other fragile situations. The role of the private sector has been widely overlooked, despite being crucial in supporting economic growth and job creation. We argue that development finance institutions have a dedicated role to play in closing financial gaps, which are widening as fragility increases. They have the comparative advantages needed to make projects happen by supporting the private sector, hence significantly contributing to the recovery process.
\end{abstract}

\section{KEYWORDS}

Private sector; development finance institutions; fragile states

\section{Introduction}

'Continental Africa was, based solely on the total number of [militarised interstate disputes] between 2002 and 2010, the most disputatious region of the world' (Palmer et al., 2015:10). Palmer et al. (2015) record 64 militarised interstate disputes in their work. In 2015, nine of the 16 United Nations peacekeeping operations were located in Africa, while continental or regional institutions such as the African Union in Somalia led other peacekeeping operations. ${ }^{1}$ New security threats from Boko Haram, the Islamic State of Iraq and Syria, and Al Shabaab have emerged. Future conflicts related to water shortages, land scarcity and degradation or climate change are highly likely, especially in Africa, where a large share of the population relies on agriculture and shocks on local agricultural prices increase the risk of violent events (Fjelde, 2015). Many states affected by conflict experience a 'conflict trap' that results in weakened state institutions and persistent instability (Collier, 2007). The key question here is: what assistance could development partners offer to move these countries out of this vicious cycle and reverse the trend?

CONTACT Thierry Giordano $\otimes$ giordano@cirad.fr E CIRAD, UMR ART-DEV - Acteurs, Ressources et Territoires dans le Développement, TA C88/15, Avenue Agropolis, 34398 Montpellier Cedex 5, France

${ }^{1}$ See the website of the United Nations peacekeeping operations: http://www.un.org/en/peacekeeping/operations/current. shtml Accessed 23 March 2015

๑ 2016 Government Technical Advisory Centre (GTAC) 
In recent years, development partners have realised the importance of following sustained prevention of conflict with economic development, as the latter is critical for reducing the incidence or probability of instability. International financial institutions (IFIs) and other regional or bilateral partners have tailored strategies to tackle specific issues related to post-conflict situations. With this understanding, IFIs have concentrated on strengthening the institutional capacity of post-conflict or fragile states, promoting democratic practices and financing 'bricks and mortar' infrastructure projects. Criticism has emerged over their slow progress (Collier, 2014) and quantum of support: more aid has to be pulled in, but how, by whom and for what?

This article makes the case for an enhanced role for development finance institutions (DFIs) specifically in post-conflict and fragile situations. DFIs can complement a number of partners: IFIs who have an extensive role to play due to more support and leeway for strategic interventions; emerging development partners who are more focused on economic opportunities serving their strategic interest; and the private sector. Thereby they could contribute to filling the wide development finance gap characterising post-conflict and fragile situations. This article focuses on how DFIs engage in post-conflict and fragile countries within their specific mandate, risk appetite and strategic plans. The article addresses the following questions in the next sections:

- Is there a gap in development finance in fragile states compared with other developing countries (Section 2)?

- Is there a dedicated role for DFIs in post-conflict countries (Section 3)?

- What are the key challenges faced by DFIs when operating in post-conflict countries (Section 4)?

- What are the minimum conditions for success (Section 5)?

\section{Post-conflict recovery and fragile states: who does what?}

Since the rise of the fragile state agenda in the 1990s, post-conflict and fragile countries have become the sole domain of IFIs followed by regional and bilateral development partners. This article posits several reasons for this phenomenon, as discussed in the following subsections. Firstly, fragility is a nebulous concept that defies clear definition, which opens the way to as many interpretations as development partners. Secondly, and as a consequence of the lack of clear definition, the approach to fragile or post-conflict states varies depending on development partner priorities. Finally, because of fragile state features and the underlying risks, official development assistance (ODA) from IFIs often remains the main source of finance into these countries. Nevertheless, other stakeholders are also involved in these interventions - mostly emerging countries and the private sector - thereby shifting the different development trajectory.

\subsection{Identifying post-conflict and fragile states}

As Giordano (2011:18) emphasises,

[T] here is a two-way link between conflict (both interstate and civil war) and fragility in the developing world: many of the fragile states are prone to conflict; and most of the countries 
emerging from conflict are fragile. Consequently, when post-conflict interventions are undertaken, countries are seen as fragile. This makes fragility the focus of the analysis.

Indeed, the main risk is for the recurrence of conflict due to the fragility of the situation. IFIs have used many terms to qualify fragility: fragile states, failed states, failing states, difficult environment and low-income countries under stress. But after the 9/11 attacks in the United States, the fragility concept has eked its way into the lexicon of the development community (Daviron \& Giordano, 2007; Grimm et al., 2014).

The World Bank - together with the Organisation for Economic Co-operation and Development (OECD), as far as the rhetoric is concerned - played a hegemonic role in shaping the policy doctrine around fragile states (Nay, 2014). Regional financial institutions such as the African Development Bank and the Asian Development Bank have followed suit. As a result, IFIs distinguish between four fragility phases and tailor their engagements accordingly: marked deterioration of security; active conflict, prolonged political crisis or impasse; post-conflict or political transition; and gradual improvement (moving towards stability). States move along this spectrum over time, and regions within the state may be differently placed on the continuum at any given time (Khadiagala \& Motsamai, 2014).

This continuum makes it difficult to identify the main features of fragile states, and complicates the process of defining fragility (Gisselquist, 2015). For the purposes of this article, we have used the definition coined by the OECD Development Aid Committee (DAC) since it evolves from a consultative process (OECD, 2012:85):

a fragile region or state has a weak capacity to carry out basic governance functions and lacks the ability to develop mutually constructive relations with society. Fragile regions or states are also more vulnerable to internal or external shocks such as economic crises or natural disasters $[\ldots]$. Fragility and resilience should be seen as shifting points along a spectrum.

Table 1. List of African fragile states and economies.

\begin{tabular}{|c|c|c|c|c|}
\hline \multirow[b]{3}{*}{ Region } & \multicolumn{4}{|c|}{ Income level } \\
\hline & \multirow{2}{*}{\multicolumn{2}{|c|}{ Low income }} & \multicolumn{2}{|c|}{ Middle income } \\
\hline & & & Lower middle & Upper middle \\
\hline $\begin{array}{l}\text { North Africa } \\
\text { Sub-Saharan Africa }\end{array}$ & $\begin{array}{l}\text { Burundi }{ }^{\mathrm{a}, \mathrm{b}} \\
\text { Central African Republic }^{\mathrm{a}, \mathrm{b}} \\
\text { Chad }^{\mathrm{a}, \mathrm{b}} \\
\text { Comoros }^{\mathrm{b}} \\
\text { Burkina Faso }^{\mathrm{b}} \\
\text { DRC }^{\mathrm{a}, \mathrm{b}} \\
\text { Madagascar }^{\mathrm{a}, \mathrm{b}} \\
\text { Malawi }^{\mathrm{b}} \\
\text { Eritrea }^{\mathrm{a}, \mathrm{b}} \\
\text { Ethiopia }^{\mathrm{b}} \\
\text { Guinea }^{\mathrm{b}} \\
\text { Guinea-Bissau }^{\mathrm{a}, \mathrm{b}}\end{array}$ & $\begin{array}{l}\text { Kenya } \\
\text { Liberiaa,b }^{\mathrm{a}, \mathrm{b}} \\
\text { Mali }^{\mathrm{a}, \mathrm{b}} \\
\text { Niger }^{\mathrm{b}} \\
\text { Sierra Leone }^{\mathrm{a}, \mathrm{b}} \\
\text { South Sudan } \\
\text { Somalia } \\
\text { Soma }^{\mathrm{a}, \mathrm{b}} \\
\text { Togo }^{\mathrm{a}, \mathrm{b}} \\
\text { Uganda }^{\mathrm{b}} \\
\text { Zimbabwe }^{\mathrm{a}}\end{array}$ & $\begin{array}{l}\text { Egypt }^{\mathrm{a}} \\
\text { Cameroon } \\
\text { Congo Rep. } \\
\text { Cote d'Ivoire }^{\mathrm{a}} \\
\text { Nigeria } \\
\text { Sudan }^{\mathrm{b}} \\
\text { Mauritania }^{\mathrm{b}}\end{array}$ & $\begin{array}{l}\text { Libya }^{\mathrm{a}} \\
\text { Angola }^{\mathrm{b}}\end{array}$ \\
\hline
\end{tabular}

Source: OECD (2014), World Bank (2015).

Notes: List of fragile states as identified by the OECD. Italics denote countries that are new on this year's OECD list. ${ }^{\mathrm{a}}$ Denotes fragile states as on the World Bank list.

${ }^{b}$ Denotes a fragile state that is also defined as a least developed country. 
Table 2. Summary of various development agencies' approaches to fragile states

\begin{tabular}{|c|c|c|c|c|c|c|}
\hline Organisation & $\begin{array}{c}\text { Asian } \\
\text { Development } \\
\text { Bank (2007) }\end{array}$ & $\begin{array}{c}\text { African } \\
\text { Development } \\
\text { Bank (2008) }\end{array}$ & $\begin{array}{l}\text { World Bank } \\
(2002)\end{array}$ & $\begin{array}{l}\text { OECD DAC } \\
(2005)\end{array}$ & USAID (2005) & AusAID (2006) \\
\hline Terminology & $\begin{array}{l}\text { Fragile and } \\
\text { conflict- } \\
\text { affected } \\
\text { situations }\end{array}$ & Fragile states & $\begin{array}{l}\text { Low-income } \\
\text { countries } \\
\text { under stress } \\
\text { (LICUS): fragile } \\
\text { and conflict- } \\
\text { affected } \\
\text { countries }\end{array}$ & $\begin{array}{l}\text { Fragile states } \\
\text { and situations }\end{array}$ & Fragile states & Fragile states \\
\hline $\begin{array}{l}\text { Objective of } \\
\text { engagement }\end{array}$ & $\begin{array}{l}\text { Improve aid } \\
\text { effectiveness }\end{array}$ & $\begin{array}{l}\text { Address } \\
\text { prevention } \\
\text { issues; } \\
\text { address } \\
\text { political, } \\
\text { economic } \\
\text { and } \\
\text { development } \\
\text { issues }\end{array}$ & $\begin{array}{l}\text { State-building, } \\
\text { peace- } \\
\text { building and } \\
\text { capacity } \\
\text { development }\end{array}$ & State-building & $\begin{array}{l}\text { Strengthen US } \\
\text { national } \\
\text { security, } \\
\text { improve } \\
\text { development } \\
\text { outcomes } \\
\text { and enhance } \\
\text { aid } \\
\text { effectiveness }\end{array}$ & $\begin{array}{l}\text { Address } \\
\text { development, } \\
\text { economic, } \\
\text { security and } \\
\text { political issues } \\
\text { in a } \\
\text { comprehensive } \\
\text { and sequenced } \\
\text { way }\end{array}$ \\
\hline
\end{tabular}

Source: UN Office of the High Representative for the Least Developed Countries, Landlocked Developing Countries and Small Island Developing States (OHRLLS, 2013: 8).

Thirty-one of the 51 fragile states identified worldwide by the OECD are African countries, while 15 of the 33 fragile states listed under the World Bank country policy and institutional assessment classification are in Africa (Table 1). The World Bank and OECD lists include a wide diverse range of countries: a few are high achievers in gross domestic product growth rates (i.e. Kenya, Angola), some have made progress towards meeting the Millennium Development Goals and improving human development (i.e. Mali, Niger, Ethiopia), and others had strong governments which suddenly collapsed (i.e. Egypt, Libya). This highlights the difficulty in defining fragile states and the lack of consensus among the international community on the critical features of fragile states (Grimm et al., 2014).

\subsection{Development partners' approaches to fragile states: state building as a priority}

Because of the aforementioned difficulty of agreeing on a common definition, and the diversity of countries classified as fragile, the international community grapples with the modalities of intervening in these countries. Risk is the common denominator of every post-conflict or fragile situation. Consequently, development institutions are faced with a partner paradox: incentives to work in post-conflict states are becoming scarce due to demands to make aid more effective. Yet they have an obligation to make post-conflict and fragile states their priority since this is where the need for external interventions is the greatest. This is not only because populations in post-conflict states are mostly poor, but also because 'they are more likely to become unstable, to destabilise their neighbours, to create refugee flows, to spread disease and to be bases for terrorists' (DFID, 2005:5). This situation has led development partners to adopt a number of different approaches over the years in relation to fragile or post-conflict states. Table 2 maps out some of those frameworks, clearly highlighting the various political motives underlying development partners' engagement in fragile states. 
Since 2008 there have been many debates on how to engage with fragile or postconflict states. In 2011, the New Deal for Engagement in Fragile States was discussed in Busan, and the Istanbul Programme of Action called for international support to least developing countries, including fragile and post-conflict countries. In February 2013, in Dili, discussions on the post-2015 agenda explored impacts on fragile and 'conflict-affected' least developing countries (Grimm et al., 2014). These discussions build on the 'good governance agenda', which emphasises the role of the state as a critical enabler of economic development through the provision of basic functions, and points out state and institutions building as strategic objectives (Marquette \& Beswick, 2011; Gisselquist, 2014). ${ }^{2}$ There is an understanding that economic development can only take place in countries that have political stability and strong institutional frameworks.

As a result of the multiplicity of frameworks, aid allocation to fragile states is hampered by a crucial lack of coordination among partners: 'donor governments and development agencies still have a long way to go if the declared objectives of policy coherence and harmonised approaches are to be reached when dealing with fragile states' (Faust et al., 2013:8).

These features influence aid allocation. Firstly, post-conflict and fragile countries have mostly been under-aided as a result of the partner paradox and high risks (OECD, 2014). Secondly, ODA is very unevenly distributed. In 2010, seven countries received half of the total ODA to fragile states - Ethiopia and the Democratic Republic of the Congo (DRC) among them - with the other 42 sharing the remainder. This led to another paradox where only a few fragile countries are over-aided while most of the others are under-aided (McGillivray \& Feeny, 2008). Thirdly, while aid to fragile states has increased from US $\$ 11.38$ billion in 2000 to US $\$ 50.04$ billion in 2010, most of this increase has been due to debt relief and not fresh finance for new development initiatives. More worrying is ODA's recent decline, which is likely to shrink again in the coming years (OECD, 2014). Fourthly, ODA to fragile states is far more volatile than aid received by other developing countries - each of the fragile states has had at least one aid shock in the past 10 years (OECD, 2013). Finally, ODA to fragile states might have lacked some level of effectiveness, although there have been improvements, as illustrated by the independent evaluation of the World Bank interventions in fragile states.

This evaluation revealed that, although the World Bank's programmes have taken cognisance of fragility, there are gaps related to the flexibility of their programmes in postconflict situations and the ability to mitigate future risks. There has been limited attention to conflict-related violence against women and the empowerment of women in conflictaffected states, and more short-term to medium-term community-driven development than long-term sustainable development (IEG, 2013).

These limits faced by development partners stress both the need for improving aid allocation and effectiveness in fragile situations, and the inherent difficulty of making statebuilding the main objective of most interventions. If development partners continue to provide assistance to post-conflict countries without thinking about larger structural

\footnotetext{
${ }^{2}$ The Worldwide Governance Indicator Project identifies six dimensions of governance: voice and accountability, political stability and absence of violence/terrorism, government effectiveness, regulatory quality, rule of law, and control of corruption (Kaufmann et al., 2010).
} 
arrangements, which implies a higher level of risks - that is, going beyond state-building and good governance to include economic growth and job creation as key objectives (Manning \& Trzeciak-Duval, 2010) - their efforts might remain ineffectual.

\subsection{Emerging development partners' strategies to fragile states: seizing economic opportunity as a priority}

Emerging countries such as China, India, Brazil, Malaysia or Indonesia are increasingly involved in Africa's development, including in post-conflict and fragile states. The China-Africa development fund was signed in 2006 at the first Forum on China-Africa Cooperation; contributing an initial US\$1 billion that will eventually grow to US\$5 billion in capital investments. India has set up its own aid agency (i.e. the Development Partnership Administration) that has budgeted US\$17 billion between 2012 and 2017; the Brazilian Development Cooperation has committed funds to their companies investing in Africa; and South Africa expects to establish its own aid agency soon (i.e. the South African Development Partnership Agency). The New Development Bank of the BRICS bloc and the Asian Infrastructure Investment Bank will also add their financial weight behind projects in the developing world.

These emerging development partners have focused on non-intervention in the internal affairs of their partners, rather than on good governance and state-building objectives. This does not prevent them from looking at institutional capacity through support of soft issues, such as technical assistance, capacity-building, system strengthening at border posts, and so forth. In fact, they do not look at fragility as a factor for involvement, but explore risk mitigation under those specific circumstances. They hence look at investment opportunities that lead to economic development. Emerging partners' interventions are almost always business oriented and often tied to their strategic economic and political interest, which is out of line with the OECD principle of untied aid, while at the same time serves private-sector development objectives that OECD-DAC members do not really address - in fragile states, most emerging development partners offer a package encompassing aid, trade and investment (OECD, 2013).

The example of China is indicative of what other emerging partners also seek to achieve. China appears to be far less risk-averse than OECD-DAC partners (Schiere, 2014). China's involvement reflects a 'new type of strategic partnership' based on mutual benefit between itself and African countries, fostering economic development while simultaneously pursuing national interests (Du Plessis, 2014). These emerging development partners thereby lend a unique slant to financing development in post-conflict or fragile countries.

\subsection{State-building and the forgotten private sector}

The evolution of post-conflict interventions has put the state at the centre of the debate, both as provider and as an institution. Development partners generally support the sovereign states, particularly through budgetary support, but in recent years the pendulum has moved towards supporting projects directly through loans and equity. A necessary requirement in both of these modalities is a well-supported and strong state. Therefore, state-building has become the priority of many development partners (see Table 2). It 
certainly is a necessary condition for development, especially in the long term, but it is definitely not sufficient for countries to engage in a virtuous cycle of development that leads to sustainable economic development for all citizens. This means that some of the roles the state should play need to be supplemented by private-sector involvement in these countries to drive economic development.

The private sector is beginning to seize opportunities in post-conflict recovery programmes, at times supported by emerging donors, as mentioned previously. Some fragile states have begun to attract foreign direct investment due to their fast growth rates, but their high risks continue to be a dampener on sustainable growth. Foreign direct investment in fragile states is increasing, mainly in oil and mining, while overlooking manufacturing and agriculture, which could produce more jobs in the long term (IMF, 2014). Oil and mining offer higher returns and therefore create incentive for private companies and investors to take more risks. As stated by the OECD (2013:42), '[t]here seems to be significant room for increased private sector flows'.

Africa's attractiveness to investors is also increasing due to phenomenal population growth, mass urbanisation, a growing middle class and a dynamic youthful population. Of course, these could be negatives too as urban infrastructure is strained, inequality grows and youths fail to find jobs in the new economies. Climate change and water availability will certainly add stress fractures to already fragile and vulnerable African countries, and in some cases might be responsible for additional conflict.

Current debates factor in the importance of private-sector involvement at an early stage of the recovery process: in generating economic development, the private sector could underscore peace efforts through job creation and economic opportunities (Gerson, 2001). In the 2014 World Economic Outlook report, the IMF pointed out that even in countries with a lower degree of investment efficiency, which characterises post-conflict countries, a one percentage point increase of gross domestic product in public investment increases output by about $2.2 \%$ in the long term (IMF, 2014). If the public and private sectors were to combine forces in post-conflict countries, the Economist's 'Aspiring Africa' narrative, which emphasises the huge potential of the continent, might be realised (The Economist, 2013). In all of these narratives, research has not sufficiently considered the role of DFIs, whose mandate is often to finance privatesector development.

\section{Is there a specific role for DFIs in post-conflict countries?}

\subsection{The nature of DFls: closing the financing gap}

DFIs or development banks ideally should narrow the gap between pure private-sector commercial loans, government grants and fiscal transfers (e.g. Development Bank of Southern Africa (DBSA) and Industrial Development Corporation (IDC) in South Africa, Banco Nacional de Desenvolvimento Econômico e Social (BNDES) in Brazil, China Development Bank (CDB) in China, Proparco in France, CDC in the United Kingdom and Kreditanstalt Für Wiederaufbau (KfW) in Germany). These are majorityowned by governments with a domestic or international mandate, or both. While de Aghion (1999:83) states that '[d] evelopment banks are government-sponsored financial institutions concerned primarily with the provision of long-term capital to industry', it 


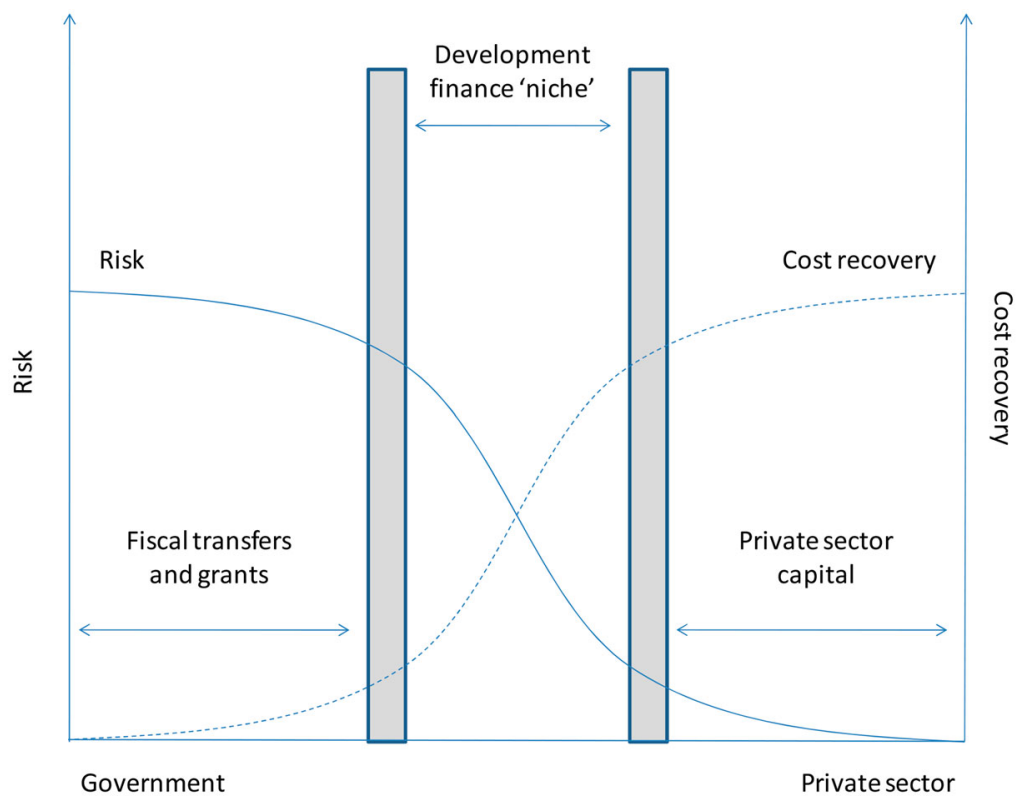

Figure 1. Financial niche of DFls.

Source: Musasike et al. (2010).

might be better to acknowledge the role DFIs play in overcoming a broader range of market failures. The lack of long-term investment is but one of the market failures encountered in many developing countries where commercial financial intermediaries tend to neglect emerging industries and avoid immature financial environments. DFIs seek to narrow the gap between public and private finance (Figure 1):

through their willingness to take political and general country risks that private sector investors have less appetite for, non-financial constraints to private sector investment in what is perceived to be economically depressed areas are mitigated and market comfort brought to fruition. This leveraging accelerates the pace at which development backlogs can be addressed. (Musasike et al., 2010:4)

When supporting the private sector, DFIs seek to demonstrate 'the benefits of successful investments to other suppliers of capital and, by so doing, raising the amount capital mobilised. This would contribute to the development of the financial sector as a whole' (te Velde \& Warner, 2007:2).

By engaging in riskier markets, DFIs might facilitate private-sector entry into those markets and pave the way for future agreements and trade:

DFIs can substantially reduce the cost of capital to borrowers by the partial transfer of a subsidy through the interest rate or the tenor (maturity and grace periods), asset and liability matching or by stipulating less onerous collateral requirements. Further, DFIs have a better understanding of developmental risk, a higher risk appetite, and a stronger risk rating, all of which they can use to benefit poorer or unrated clients. The inclusion of more commercially orientated projects in their portfolios also allows them to cross-subsidise development projects in poor areas. (Musasike et al., 2010:4) 


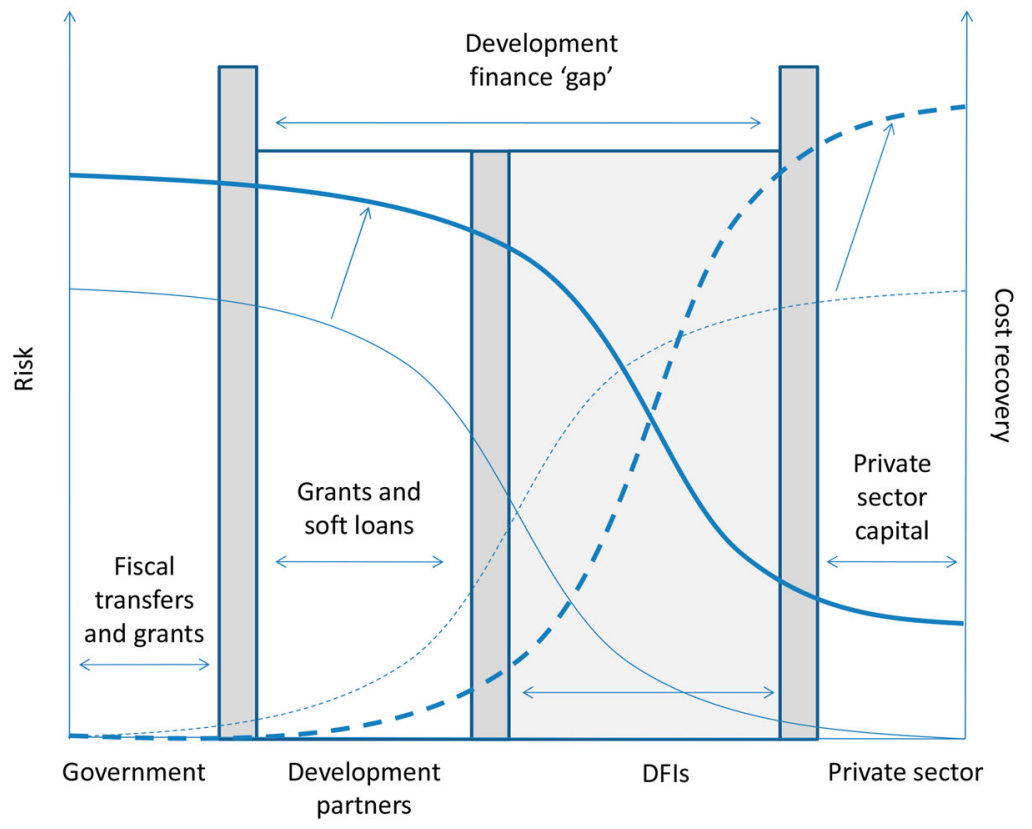

Figure 2. DFI role in post-conflict and fragile situations.

Source: Authors.

Hence DFIs have a higher risk tolerance and a longer investment horizon.

In today's world, DFIs should have a triple bottom line, encompassing their economic, social and environmental impacts. In post-conflict or fragile countries, however, DFIs, like other external actors, do not want to undermine the state-building process. DFIs are meant help the private sector enter high-risk markets by facilitating the creation of an environment conducive to the protection of private-sector investments and interests (governance, rule-based structures, etc.), along with the provision of social and environmental goods and services. But they have to find ways of doing so without weakening the state as a decision-making and policy formation entity (OECD, 2010).

\subsection{DFls in fragile situations}

The development finance gap in post-conflict and fragile situations differs critically from that described in the previous section, as shown in Figure 2. Firstly, post-conflict governments have fewer resources for public investment than stable countries due to the low capacity to absorb finance and the low levels of tax collection (OECD, 2014). This pushes the government's finance capacity to the left. Secondly, the threshold of private-sector engagement becomes much lower than in other countries, pushing its limit to the right. At the same time, private companies and investors perceive much higher and broader risks, thereby pushing the risk curve up and to the right. This is mainly due to the limited state capacity to develop a conducive and trusting environment for private-sector involvement, and to the difficulty that development partners have in addressing these 
drawbacks in ways other than those related solely to state-building. The development finance gap is widening considerably as a consequence of limited state resources and increased risks.

IFIs and other regional and bilateral development partners who provide mostly grants and soft loans to support state-building partially close this gap. However, because ODA remains very volatile and unevenly distributed, the gap-closing capacity of development partners varies widely over time. Emerging development partners are mostly private sector oriented, and thereby partly complement state-building interventions. However, their strategy based on both non-intervention in the internal affairs of partner countries and support to economic opportunities guided by national interests remains highly selective and thereby constrains their ability to close the development finance gap.

A financial niche thus remains for DFIs. Because of their knowledge of working in difficult environments and the tools they have at their disposal, they aim to 'address the capital market inefficiencies where private capital is unwilling or unable to bear the risk of providing capital to countries, projects or clients that are not considered creditworthy' (Musasike et al., 2010:3). One additional advantage DFIs have is the willingness to finance 'public goods' or socio-economic projects with no clear economic reward, which the private sector has been reluctant to finance (Thorne \& du Toit, 2009).

Indeed, to achieve their mission, DFIs have at their disposal several instruments that commercial banks do not ordinarily have (te Velde \& Warner, 2007): capital or sovereign guarantees; dividend and/or tax exemptions; subsidies for debt financing (lower interest rates, longer maturity, grace period, foreign currency debt payment, loan structure); subsidies for equity financing (discounted rate of return, lower expected dividends); and technical assistance (feasibility study, project management). This wide array of instruments allows them to adapt to many situations, including post-conflict and fragile environments. However, in such difficult countries, they can only close the financing gap when private investments actually support local economic development.

\section{How could the private sector support economic development in post- conflict and fragile situations?}

There is no reason a priori to expect that the perception of Africa as a 'market' open for business will preferably trigger development rather than simply perpetuate the interest of big capital. This is especially true in fragile environments. A weak government will not be able to ensure that market economy benefits will reach parts of society that need developing; therefore, the risk of triggering conflicts is high. However, despite market and government failures, private investments can make a difference and support recovery.

\subsection{Market and government failure: who manages the risk?}

Market failure, defined as the inefficient allocation of resources in a free market, is responsible for perceived inadequacies of the private sector. In many developing countries, market failure is so substantial that it spells a loss of private-sector interest in project development and financing. Ideally, a benevolent government should develop policies - be they incentives or command and control regulations - to overcome these failures and ensure an enabling environment in which the private sector could expand profitably. Unfortunately, 
in these same developing countries, governments also tend to fail because they do not have the capacity and/or the willingness to address market failure. Consequently, the involvement of the private sector is limited and the economic and social benefits do not peak, as they do when markets are operating optimally. The situation is even more worrying in fragile environments where weak formal institutions and poor governance are prevalent.

Games (2011) cites the high cost of doing business in Africa as the main limitation to private companies entering those markets. Moreover, poor or non-existent infrastructure, regulatory and tax uncertainty, difficult and expensive logistics, a surfeit of bureaucracy, the absence of effective legal frameworks, corruption, skill shortages and currency fluctuations make businesses far more cautious about entering new markets in Africa. Finally, secondary risks include those related to language and business culture differences, the choice of local partners, a weak local private sector, a lack of market information, weak government institutions, work permit issues, non-payment, a trend towards local content and empowerment, operating licence requirements, tender delays and costs of tendering, and security of people and assets. The riskier the investment, the higher the expected returns; that is, the more expensive the finance. To some extent, when risks are too high, investments do not make economic sense because finance becomes overpriced, which is when governments need to become risk managers by developing policies aimed at reducing or reallocating risks - even though a government will never be a perfect risk manager (Moss, 2002:49-52). In fragile environments, not only do governments generally fail to play this risk manager role, they tend to generate more risks by pursuing political rather than collective interests in the search for political longevity.

What the private sector does require is a government that facilitates market functionality and ensures the protection of private-sector interests. Public-private partnerships (PPPs) or public-private investments have become an emblematic tool in generating private-sector involvement and delivering economic and social benefits to local populations. PPP frameworks are being developed across Africa to ensure that private-sector interest is protected through enabling legislation and facilitating the 'ease of doing business'. While PPPs have been rather successful in some instances (Simon et al., 2014), they are not, however, the panacea because regulatory frameworks have not caught up, in many instances, with the demand for new partnerships between public and private sectors, and institutional capacities have been limited for PPPs to succeed (Trebilcock \& Rosenstock, 2015). Of course, these institutional capacities are even scarcer in fragile environments. The private sector therefore tends to be crowded out.

\subsection{Extractive industries as first investors ...}

As a direct consequence of the lack of risk management by governments in post-conflict and fragile states, industries in the extractive sector are the first investors because this sector delivers high returns on investment, hence encouraging companies to take more risks. Generally, development partners view extractive industries as a hurdle rather than an opportunity for recovery as controversy has emerged on the role of natural resources in fuelling conflict and delaying peace (Ron, 2005; Brunnschweiler \& Bulte, 2009; Bhattacharyya \& Collier, 2014). It would be hasty to conclude that what has been commonly named the 'resource curse' would inevitably lead to a conflict trap, although that conclusion would be correct if the gains obtained through resource extraction were corruptly invested offshore or 
misdirected to sectors that do not generate overall economic growth. The question is not whether foreign direct investment is undesirable because of its potentially harmful effect, but rather how to make the most of investments, profit and social services in the recovery process, especially for the benefit of local communities. In this regard, voluntary initiatives such as the Kimberley process for certifying diamond origins for the prevention of blood diamond trade, and the 'publish what you pay' initiative that calls for transparency in countries' investments in the developing countries, help create an enabling environment for private-sector involvement. In addition, the extractive industries transparency initiative that calls for clear regulations in disclosing interests in natural resources has encouraged private companies to modify their practice, to collaborate in conflict prevention initiatives and to encourage their investments in those countries. This engagement in extractive industries demonstrates that capital intensive and risky investments by financially strong and large companies are possible today in Africa when the project is of economic and strategic importance.

\section{3. ... But not only}

Beyond extractive companies, foreign investors are reluctant to go into post-conflict and fragile states despite the advantages of being the first mover or benefits from loose regulatory frameworks. They engage with post-conflict or fragile countries mainly through contracts with the government or, more directly, development agencies to provide goods and services (Haufler, 2007). Interestingly, private investments thrive in sectors such as telecommunications (mostly mobile phone hardware and software), banking services, manufacturing or other services.

The fairly high degree of scepticism in boardrooms, particularly those in South Africa, is largely due to perceptions of risk, rather than the experience of it, with a dose of Afropessimism, exacerbated by poor local media coverage of business on the continent and the media's emphasis on incidents of political instability - but emerging markets interest in Africa has eroded some of these doubts. 'DFIs have a particular role to play in facilitating and underwriting deals that involve state-owned enterprises in other African countries' (Games, 2011:12).

DFIs could facilitate entry of the private sector into African markets. They would provide a risk-limiting springboard into the region as an initiator and guarantor of projects. Once DFIs enter a region, the private sector would follow suit and begin to engage with potentially rewarding markets in which they had not previously ventured.

\section{What are the conditions for success?}

While DFI risk profiles are meant to be greater than those of commercial banks, it is often suggested that these profiles might be pitched well above actual risk in post-conflict and fragile markets. As a result, the ability of DFIs to overcome financial market failure is restricted, which undermines their potential to impact positively on development. Looking at bilateral, regional and multilateral DFIs, te Velde \& Warner (2007) question the willingness of DFIs to take higher risks to promote private investment. However, DFI involvement cannot be limited to their appetite for risk. They need to consider at least four factors: their ability to go beyond a superficial analysis of risks; their potentially 
Table 3. SADC country ratings in 2010 and 2015.

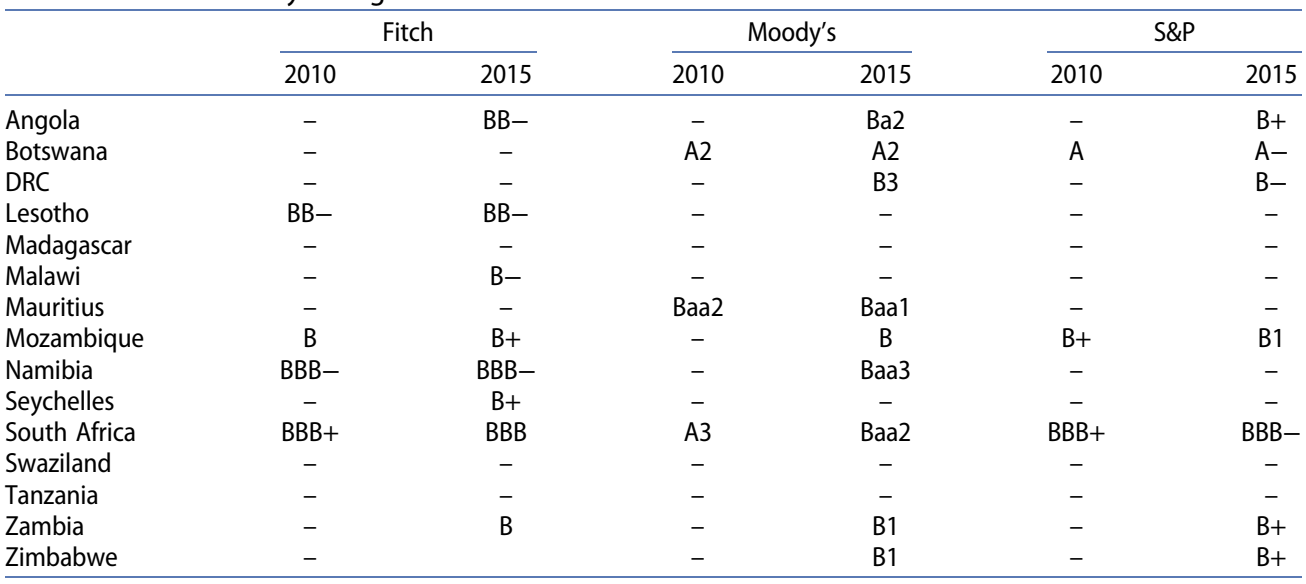

Source: Fitch: https://www.fitchratings.com/site/fitch-home/sovereigns, Moody's: https://www.moodys.com/researchan dratings/market-segment/sovereign-supranational/-/005005/4294966293/4294966623/-1/0/-/0/-/-/en/global/rr, S\&P: https://www.standardandpoors.com/en_AP/web/guest/home websites, accessed 23 March 2015.

strong impact on development in a context where a first move counts; the positive ripple effect on improvement of the investment climate; and their participation in the statebuilding process or in doing no harm (OECD, 2010). The first two are particularly relevant for DFIs working in African fragile and post-conflict countries.

\subsection{Addressing the risk perception issue}

The most expected outcome of increased private investment in fragile situations would be a very high rate of project failure because of the high levels of risk, with the main reason being an unfamiliar environment where information is limited and perceptions of risk are high. DFIs will need to understand and mitigate perceived systemic risk to address the misperception of risks in developing countries more generally, and in post-conflict countries specifically.

An in-depth evaluation of a risk must rely on information that is generally not available in post-conflict or even stable African states. Warnholz (2008) attributes this to the pervasive information deficit about African markets. Table 3 presents credit ratings published by the main rating agencies for the Southern African Development Community (SADC) region. Firstly, rating agencies rate more countries now than in 2010, reflecting easier access to information in international markets. Secondly, the major rating agencies did not rate one of the few fragile countries of the region in 2010, while they only rated the DRC in 2015. In countries with no sovereign debt rating, companies find it difficult to access the international credit market, although the early-2015 bond uptake in Tanzania proves that opportunities sometimes outweigh the perceived risk. ${ }^{3}$ African institutions rely heavily on international assessments of their economic and social well-being. In the current context, not many DFIs could play the role of information collators because

\footnotetext{
${ }^{3}$ The Economist Intelligence Unit asserts that Tanzania's sovereign risk score is in the 'middle of the B rating band': http:// country.eiu.com/article.aspx?articleid $=1201767304 \&$ Country=Tanzania\&topic=Risk\&subtopic=Credit \pm risk\&subsubtopic= Sovereign \pm risk\&aid=1\&oid=28321787 Accessed 23 March 2015
} 
their capacity to do so is weak and they are faced with so many other institutional challenges. Ideally, DFIs should collate necessary information in this context to provide a public good.

This does not mean that a sovereign rating is sufficient to evaluate risk, especially in fragile environments. For instance, instability in the Kivu region in the DRC does not mean that the Katanga region is also unstable, despite the fact that the country rating is the same for the two provinces. Consequently, there is a need for more precise and reliable information, which could include a thorough assessment of risks of different regions and sectors within countries.

DFIs thus need to address risk perceptions through their willingness to operate in difficult environments. Developing data collection processes and appropriate techniques to identify probabilities associated with a range of events may solve only part of the problem. At the same time, checks and balances may be required to avoid potential biases in the way DFIs estimate risks. This latter element is crucial for DFIs where development impact and development results are as important as financial results.

A final risk perception is that certain DFIs perceive Africa as a highly risky continent in terms of doing business and investing. A continued perception of Africa as the 'dark continent', or one in which corrupt government officials and business people are just waiting for hapless internationals to invest their money, taints business relationships on the continent and makes business expensive and 'high risk'. Only transparent and informative processes and regular business contacts could allay these fears.

\subsection{Introducing reflexivity: development impact assessment}

DFIs should take project impacts into account when evaluating risks, and thereby select the most impactful sectors depending and local contingencies. As development institutions, DFIs include these criteria in the credit pricing since the higher the project's social and economic impact, the higher the potential stabilising effect of the project. A project should be identified as a priority for most local stakeholders, including the local population, and should fit into the development strategy of public authorities (including the government), while not undermining local accountable institutions (local government or chiefdom, communities, etc.). Because financing these projects might enhance future stability, it might also reduce future risks, facilitate future investment and hence create a virtuous development cycle out of conflict and poverty. DFIs should therefore target under-invested - and therefore riskier - countries and sectors with projects with high social, environmental and economic impact, and balance these impacts against existing risks so as not to jeopardise the financing of projects. By measuring the development impact of projects, DFIs are in a position to determine whether they need to be risk averse or risk tolerant, and in which sectors, through impact assessment tools based on four pillars: financial performance; economic performance; environmental and social performance; and private-sector development (Kingombe et al., 2011).

\section{Conclusion}

Is there a role for DFIs in post-conflict countries? Current analyses of post-conflict interventions lack emphasis on economic recovery while stressing public and private 
interventions in state-building initiatives. Economic recovery is a crucial step towards exiting the conflict trap. The present article makes the case for a potential role for DFIs in closing part of the financial gap, which becomes increasingly wider as fragility increases. DFIs theoretically have the comparative advantages needed to implement projects by supporting the private sector, and hence to significantly contribute to the recovery process. They have the tools required to take higher risks, the knowledge to intervene in difficult environments and the capacity to raise funds. Therefore, they should be able to strengthen local initiatives, especially those aimed at job creation and raising revenue to support the stabilisation process. Indeed, successful projects could yield a significant development impact, especially since the needs are so overwhelming in post-conflict and fragile countries that a new project of significant economic and social importance has a potentially high impact.

However, DFIs need to overcome at least four hurdles. The first relates to the difficulty to assess risks in post-conflict countries due to the lack of both information and experience. This implies that special effort is needed for DFIs to collect information and develop their own risk assessment tools so as to go beyond the perceived risk syndrome. It also provides DFIs with opportunities to take the lead in projects in regions with postconflict member states. The second hurdle is probably to learn from the private sector. While some private companies are actually able to take on risks to develop projects in such difficult contexts - most of the time the high rewards offset the risks they take others can simply not cope with situations fraught with difficulties. Third, DFIs must understand the specificities related to every post-conflict situation and find best practices to identify the most import sectors to support, craft and influence private initiatives so as to maximise the development impact of their interventions.

While DFIs have an important role to play in post-conflict and fragile situations, a last hurdle is not specific to these difficult situations. It relates to the ability of DFIs to close the development finance gap. Many DFIs have institutional capacity shortcomings and inadequate staffing that could hamper their processing of applications for finance and the identification of priority investments and bankable projects (Banda, 2014). Institutional weaknesses and capacity constraints added to budgetary shortfalls result in a failure of DFIs to respond to national or regional development needs. In some cases, political agendas hold DFIs hostage as governments' link project identification and development to their terms in power. Unless this last hurdle is overcome, the potential of DFIs in closing the development finance gap will vanish.

\section{Disclosure statement}

No potential conflict of interest was reported by the authors.

\section{References}

de Aghion, BA, 1999. Development banking. Journal of Development Economics 58, 83-100.

Banda, L, 2014. A scan of national development finance institutions in the SADC region: SADC Development Finance Resource Centre for SADC DFI Network.

Bhattacharyya, S \& Collier, P, 2014. Public capital in resource rich economies: Is there a curse? Oxford Economic Papers 66(1), 1-24. 
Brunnschweiler, CN \& Bulte, EH, 2009. Natural resources and violent conflict: Resource abundance, dependence, and the onset of civil wars. Oxford Economic Papers 61(4), 651-74.

Collier, P, 2007. The bottom billion: Why the poorest countries are failing and what can be done about it. Oxford University Press, Oxford.

Collier, P, 2014. Fragile African states: What should donors do? Working Paper 95, FERDI.

Daviron, B \& Giordano, T, 2007. Etats fragiles: genèse d'un consensus international. In Châtaigner, J-M \& Magro, H (Eds.), Etats et sociétés fragiles, entre conflits, reconstruction et développement. Karthala, Paris.

DFID (Department for International Development [United Kingdom]), 2005. Why we need to work more effectively in fragile states. Department for International Development, London.

Du Plessis, A, 2014. The Forum on China-Africa cooperation, ideas and aid: National interest(s) or strategic partnership? Insight on Africa 6(2), 113-30.

Faust, J, Grävingholt, J \& Ziaja, S, 2013. Foreign aid and the fragile consensus on state fragility. Journal of International Relations and Development 18(4) 407-27.

Fjelde, H, 2015. Farming or fighting? Agricultural price shocks and civil war in Africa. World Development 67, 525-34.

Games, D, 2011. Doing business in post-conflict/fragile states: Challenges and risks. Working Paper Series No. 23. Development Bank of Southen Africa, Midrand.

Gerson, A, 2001. Peace building: The private sector's role. The American Journal of International Law 95(1), 102-19.

Giordano, T, 2011. Agriculture and economic recovery in post-conflict countries: Lessons we never learnt. Working Paper Series No. 22. Development Bank of Southen Africa, Midrand.

Gisselquist, RM, 2014. Aid and institution-building in fragile states: What do we know? What can comparative analysis add? The ANNALS of the American Academy of Political and Social Science 656(1), 6-21.

Gisselquist, RM, 2015. Varieties of fragility: Implications for aid. Third World Quarterly 36(7), 1269-80.

Grimm, S, Lemay-Hébert, N \& Nay, O, 2014. 'Fragile states': Introducing a political concept. Third World Quarterly 35(2), 197-209.

Haufler, V, 2007. The private sector and governance in post-conflict societies. In Brinkerhoff, DW (Ed.), Governance in post-conflict societies. Routledge, New York.

IEG (Independent Evaluation Group), 2013. World Bank Group assistance to low-income fragile and conflict-affected states: An independent evaluation. Washington, DC, The Word Bank.

IMF, 2014. World economic outlook: Legacies, clouds, uncertainties. International Monetary Fund, Washington, DC.

Kaufmann, D, Kraay, A \& Mastruzzi, M, 2010. The worldwide governance indicators: A summary of methodology, data and analytical issues. World Bank Policy Research Working Paper No. 5430, World Bank.

Khadiagala, GM \& Motsamai, D, 2014. The political economy of intrastate conflicts. In Malone, D, Medhora, R \& Currie-Adler, B (Eds.), International development: Ideas, experiences, and prospects. Oxford University Press, Oxford.

Kingombe, C, Massa, I \& te Velde, DW, 2011. Comparing development finance institutions: Literature review. Overseas Development Institute, London.

Manning, R \& Trzeciak-Duval, A, 2010. Situations of fragility and conflict: Aid policies and beyond. Conflict, Security \& Development 10(1), 103-31.

Marquette, H \& Beswick, D, 2011. State building, security and development: State building as a new development paradigm? Third World Quarterly 32(10), 1703-14.

McGillivray, M \& Feeny, S, 2008. Aid and growth in fragile states. Research Paper No. 2008/03: United Nation University, WIDER.

Moss, DA, 2002. When all else fails: Government as the ultimate risk manager. Harvard University Press, Cambridge, MA.

Musasike, L, Stilwell, T, Makhura, M, Jackson, B \& Kirsten, M, 2010. Lessons from Southern Africa. In Caprio, G, Fiechter, J, Litan, RE \& Pomerleano, M (Eds.), The future of state-owned financial institutions. Brookings Institution Press, Washington, DC. 
Nay, O, 2014. International organisations and the production of hegemonic knowledge: How the World Bank and the OECD helped invent the fragile state concept. Third World Quarterly 35 (2), 210-31.

OECD (Organisation for Economic Co-operation and Development), 2010. Do no harm: International support for statebuilding. In Conflict and Fragility. OECD, Paris.

OECD (Organisation for Economic Co-operation and Development), 2012. Improving international support to peace processes: The missing piece, conflict and fragility. OECD Publishing, Paris.

OECD (Organisation for Economic Co-operation and Development), 2013. Fragile states: Resource flows and trends, conflict and fragility. OECD Publishing, Paris.

OECD (Organisation for Economic Co-operation and Development), 2014. Fragile states 2014: Domestic revenue mobilisation in fragile states. OECD, Paris.

OHRLLS, 2013. Effective support for fragile and post-conflict least developed countries: Fragility as a development challenge. UN Office of the High Representative for the Least Developed Countries, Landlocked Developing Countries and Small Island Developing States.

Palmer, G, D’Orazio, V, Kenwick, M \& Lane, M, 2015. The MID4 dataset, 2002-2010: Procedures, coding rules and description. Conflict Management and Peace Science 32(2), 222-42.

Ron, J, 2005. Paradigm in distress? Primary commodities and civil war. Journal of Conflict Resolution 49(4), 443-50.

Schiere, $\mathrm{R}, 2014$. The impact of China on the donor landscape in African fragile states. IDS Bulletin 45(4), 46-56.

Simon, J, Schellekens, O \& de Groot, A, 2014. Public private partnership and development from the bottom up - from failing to scaling. Global Policy 5(1), 121-26.

The Economist, 2013. Aspiring Africa. March, 2.

Thorne, J \& du Toit, C, 2009. A macro-framework for successful development banks. Development Southern Africa 26(5), 677-94.

Trebilcock, M \& Rosenstock, M, 2015. Infrastructure public-private partnerships in the developing world: Lessons from recent experience. The Journal of Development Studies 51(4), 335-54.

te Velde, DW \& Warner, M, 2007. The use of subsidies by Development Finance Institutions in the infrastructure sector. ODI Working Paper No. 283, Overseas Development Institute.

Warnholz, JL, 2008. Is investment in Africa low despite high profits? CSAE WPS/2008-31: Centre for the Study of African Economies.

World Bank, 2015. Harmonized list of fragile situations FY15. World Bank, Washington, DC.

World Bank, 2002. World Bank Group work in low-income countries under stress - A task force report. World Bank, Washington, DC. 